\title{
Behavioral Sensitization, Alternative Splicing, and D3 Dopamine Receptor-Mediated Inhibitory Function
}

\author{
Neil M Richtand*, , 2 \\ ' Psychiatry Service (VI I 6A), Cincinnati Veterans Affairs Medical Center, Cincinnati, OH, USA; ${ }^{2}$ Department of Psychiatry, University of Cincinnati \\ College of Medicine, Cincinnati, OH, USA
}

\begin{abstract}
Behavioral sensitization, the progressive and enduring augmentation of certain behaviors following repetitive drug use, alters rodent locomotion in a long-standing manner. The same dopamine pathways playing an important role in drug dependence and psychosis also play a critical role in sensitization. Individual dopamine receptor subtypes have markedly different functional responses to stimulation, with D3 dopamine receptor stimulation inhibiting rodent locomotion. The D3 receptor has highest affinity of the dopamine receptor subtypes for dopamine, and is occupied to a greater degree following stimulant drug administration. D3 receptor activity may be regulated through the expression of an alternatively spliced, truncated receptor isoform (termed 'D3nf') altering receptor localization and function via dimerization with the full-length subunit. The expected physiological response to repetitive drug administration is tolerance. Tolerance of D3 receptor inhibition of locomotion would contribute to sensitization to stimulant drugs. We hypothesize that repetitive D3 receptor stimulation contributes to the development of behavioral sensitization through decreased responsivity of D3-receptor-mediated locomotor inhibition. Increased D3nf expression may direct altered receptor localization and subsequent release of D3-receptormediated inhibition, contributing to the expression of sensitization. These hypotheses follow directly from the affinities of the receptor subtypes for dopamine; dopamine concentrations following stimulant administration; the effects of individual dopamine receptor subtype stimulation on locomotion; and the expected homeostatic response of the system to perturbation by drug. Clarifying these mechanisms underlying sensitization may suggest new interventions for neuropsychiatric conditions in which dopamine plays an important role, including psychosis, drug dependence, and Parkinson's disease. This information may also elucidate a previously unrecognized mechanism regulating receptor trafficking and desensitization.

Neuropsychopharmacology (2006) 3 I, 2368-2375. doi:I0.1038/sj.npp. I 30 I I63; published online 19 July 2006
\end{abstract}

Keywords: dopamine; D3nf; amphetamine; locomotor activity; animal model; drug dependence

\section{INTRODUCTION}

Although David Segal has sadly passed away, he leaves as one legacy to those who were fortunate to have had the opportunity to know and admire him, an enduring interest in the paradox of behavioral sensitization. Behavioral sensitization, the progressive and long-lasting augmentation of certain behaviors following repetitive stimulant drug administration (Segal and Mandell, 1974), is a well-studied model of behavioral plasticity. Following repeated, intermittent treatment with stimulant drugs such as amphetamine (AMPH) or cocaine, sensitized behaviors may occur more intensely, with shorter latency, and/or at lower dose than before sensitization (Segal et al, 1980). The paradox of

*Correspondence: Dr NM Richtand, Department of Psychiatry, University of Cincinnati College of Medicine, 231 Albert Sabin Way, ML0559, Cincinnati, OH 45267, USA, Tel: + I 513558 6657, Fax: + I 513558 0042, E-mail: neil.richtand@uc.edu

Received 13 January 2006; revised 3 I March 2006; accepted 4 April 2006

Online publication: 9 June 2006 at http://www.acnp.org/citations/ Npp060906060026/default.pdf sensitization is that the expected response of a biological system to repetitive stimulation is tolerance, rather than augmentation of the behavioral response. David's view of this was that it captured the essence of science: that both the work, and the joy, of science begin with the unexpected result, in determining a context in which the unexpected finding fits logically and make sense with the other pieces of the puzzle, that is, in making the paradox unparadoxical. Here we describe a theoretical model of behavioral sensitization, which attempts to do that, by viewing sensitization as tolerance of inhibitory systems, rather than an increase following repeated drug exposure. Evidence for the role of the dopamine D3 receptor in this adaptation is presented, and RNA alternative splicing is suggested as a possible underlying mechanism.

\section{DEVELOPMENT VS EXPRESSION OF BEHAVIORAL SENSITIZATION}

Behavioral sensitization may be separated into two distinct components, both temporally and spatially, termed 'development' (or 'initiation'), and 'expression.' Initiation of 
sensitization involves both D1 dopamine (DA) receptor and glutamate receptor activation within ventral tegmentum and substantia nigra (Bjijou et al, 1996; Wolf et al, 1995; Kalivas and Alesdatter, 1993). Projections from prefrontal cortex and amygdala also participate in the initiation of sensitization (Wolf, 1998). Expression of sensitization, in contrast, is believed to result from changes in the nucleus accumbens. In general, changes in the ventral tegmentum believed to be related to the initiation of sensitization are transient, such as decreased sensitivity of somatodendritic D2 subtype dopamine autoreceptors (Kamata and Rebec, 1984; White and Wang, 1984; Henry et al, 1989; Ackerman and White, 1990). In contrast, neurochemical changes in the nucleus accumbens accompanying sensitization are persistent (Wolf, 1998), such as increased D1 receptor electrophysiological responsiveness (Henry and White, 1991; Higashi et al, 1989) and upregulation of cAMP signal transduction (Nestler et al, 1990; Terwilliger et al, 1991). Some of the changes in the nucleus accumbens, such as augmentation of the increase in extracellular dopamine elicited by stimulants (Robinson et al, 1988; Kalivas and Duffy, 1990), require a withdrawal time interval to be manifest. The augmentation in behavioral response is an enduring alteration, persisting for at least 1 year in rats (Paulson et al, 1991). Evidence from several labs suggests sensitization is dependent on new protein synthesis (Karler et al, 1993; Sorg and Ulibarri, 1995).

\section{BEHAVIORAL CHARACTERISTICS OF SENSITIZATION}

In humans, sensitized behaviors following repetitive stimulant drug administration frequently include psychotic symptoms of paranoia, ideas of reference, and auditory and visual hallucinations in otherwise healthy individuals (Ellinwood, 1967; Griffith et al, 1972; Utena, 1966; Sato et al, 1983). Human symptoms following repetitive stimulant drug use evolve gradually from intense curiosity, progressing to intense exploration of the environment, which may be displayed in repetitive stereotyped searching, sorting, and examining behaviors. This curious 'suspiciousness' of the environment later evolves into paranoia and psychotic thought (Ellinwood et al, 1973; Segal et al, 1981; Segal and Schuckit, 1983). Because pretreatment with AMPH facilitates the later acquisition of drug self-administration in rodents (Piazza et al, 1989), it has also been theorized that sensitization may underlie the development of drug craving, and thus initiate addictive behaviors seen in human drug dependence (Robinson and Berridge, 1993).

Specific behaviors sensitized in rodents depend upon drug dose, with stimulant-induced locomotion enhanced following sensitization with low doses of stimulant drug. At higher drug doses, sensitization of stereotyped behaviors emerges. The initial increase in exploratory locomotion, and later repetitive-focused stereotyped movements observed in rats with progressively increasing drug dose, is in some respects analogous to the evolution of the human behavioral pattern of response to stimulants. Although this description highlights common features shared by rodent behavioral sensitization and the development of psychosis in man (Segal and Mandell, 1974; Segal et al, 1981; Bell, 1973; Segal and Schuckit, 1983; Sato et al, 1983; Lieberman et al, 1997), the rodent brain and behavioral repertoire is far more limited and less complex than its human counterpart, and there is no direct correspondence between rodent behavioral sensitization and human psychiatric disease. There is, however, strong evidence that behavioral sensitization is related in large part to plasticity of limbic neurochemical systems, which also play an important role in a range of psychiatric and substance use disorders. Thus primitive, highly conserved structures modulating emotional homeostasis are likely shared by systems contributing to behavioral sensitization, psychosis, and drug dependence.

\section{DOPAMINE AND BEHAVIORAL SENSITIZATION}

Brain DA systems play an important role in behavioral sensitization, as demonstrated in lesion studies (Creese and Iversen, 1975; Creese and Iversen, 1972; Fog et al, 1970; Roberts et al, 1975; Pijnenburg et al, 1975; Costall and Naylor, 1974), and microinjection studies of both dopamine agonists (Hitzemann et al, 1980; Kalivas and Weber, 1988; Vezina and Stewart, 1990) and antagonists (Stewart and Vezina, 1989). Dopamine-mediated effects occur through interaction with two pharmacologically distinct receptor families, D1 family (including D1 and D5 receptors) and D2 family (D2, D3, and D4 receptors).

D3 dopamine receptor mRNA and protein expression are limited primarily to olfactory tubercle, nucleus accumbens, and islands of Calleja (located ventral to the ventral pallidum and nucleus accumbens), phylogenetically ancient limbic brain regions linked to motivated and emotional behaviors (Levesque et al, 1992; Bouthenet et al, 1991; Richtand et al, 1995; Landwehrmeyer et al, 1993; Gurevich and Joyce, 1999; Levant, 1998). Protein and mRNA expression are highly colocalized, suggesting that receptor expression occurs primarily on perikarya, proximal dendrites, and short axons as opposed to long axon terminals from other brain regions (Levesque et al, 1992).

Because D3 receptors exhibit functional as well as physical interactions with both D1 and D2 receptors (Scarselli et al, 2001; Zeng et al, 2006), it is of interest that receptor colocalization studies indicate that D1 and D3 receptors are coexpressed in islands of Calleja, nucleus accumbens, and caudate (Schwartz et al, 1998; Ridray et al, 1998; Surmeier et al, 1996; Le Moine and Bloch, 1996). In human brain, most D3 mRNA-expressing cells also express D2 mRNA (Gurevich and Joyce, 1999), whereas in rodent brain, in contrast, D2 and D3 receptors appear to have predominantly complementary rather than overlapping patterns of expression (Bouthenet et al, 1991). In the nucleus accumbens shell, colocalized D1 and D3 receptors exert synergistic effects on substance $\mathrm{P}$ gene expression (Ridray et al, 1998; Schwartz et al, 1998). In contrast, D1 and D3 receptor activation in the islands of Calleja exert opposite effects on c-fos expression, presumably through opposing actions on adenylate cyclase activity (Ridray et al, 1998; Schwartz et al, 1998). Similarly, D2 receptors in the nucleus accumbens core and D3 receptors in the nucleus accumbens shell region play opposing roles in neurotensin expression (Diaz et al, 1994).

D3 receptor occupation by agonist appears to inhibit neuronal firing (Liu et al, 1994a). Following stimulant drug 
administration, D1 and D3 receptors exert opposing effects on intracellular signaling pathways and gene expression through opposite regulatory effects on extracellular signalregulated kinase (ERK) activity and expression of Fos family genes (Zhang et al, 2004). Behaviorally, although acute concurrent D1/D2 dopamine receptor activation stimulates rodent locomotion (Dalia et al, 1998; Dreher and Jackson, 1989), D3 receptor stimulation inhibits both novelty-stimulated locomotion (Pritchard et al, 2003; Xu et al, 1997; Menalled et al, 1999; Ekman et al, 1998; Accili et al, 1996) and AMPH-stimulated locomotion (Waters et al, 1993). One model, as presented in this paper, suggests the loss of a D3 receptor-mediated 'brake' on these behaviors would be expressed as the emergence of augmented locomotor response to novelty and AMPH in rodents, and might also be expressed as paranoid psychotic symptoms in humans.

\section{D3 DOPAMINE RECEPTOR THEORY OF SENSITIZATION}

Dopamine receptor subtypes differ widely in affinity for dopamine and the dopamine concentration range over which receptor occupancy varies and alterations in cellular signaling occur. The D3 receptor has highest affinity for dopamine, with low-affinity state $K_{\mathrm{i}}=30 \mathrm{nM}$ (Sokoloff et al, 1992), close to basal extracellular (3-5 nM; Kalivas and Duffy, 1993; Parsons and Justice, 1992) and synaptic dopamine concentrations (50 nM; Ross, 1991). In contrast, D1 and D2 receptor affinity for dopamine are far lower: D2 $K_{\mathrm{i}}(\mathrm{nM})=2000$ and $\mathrm{D} 1 K_{\mathrm{i}}(\mathrm{nM})=2300$ (Sokoloff et al, 1992). Following stimulant drug administration, dopamine concentrations are elevated for prolonged periods (Jones et al, 1996a,b), with average concentrations of $750 \mathrm{nM}$ (Zetterstrom et al, 1983). At that dopamine concentration, calculated low-affinity state receptor occupancy is $96 \%$ for D3 receptor, compared to $25 \%$ for D1 and $27 \%$ for D2 receptor. These differences in receptor occupancy suggest the likelihood that tolerance would develop differentially for each of the three-receptor systems, with greatest tolerance of D3-receptor-mediated inhibitory effects. The D3 dopamine receptor behavioral action as a 'brake' on locomotion suggests that tolerance of this inhibition would contribute to sensitization (Richtand et al, 2001a,b).

\section{D3 DOPAMINE RECEPTOR ALTERNATIVE SPLICING}

The single gene coding for the D3 receptor is organized to allow for the production of different transcripts via alternative splicing of D3 receptor heteronuclear-RNA (hn RNA or pre-mRNA) in the cell nucleus, as illustrated in Figure 1 (Griffon et al, 1996; Fu et al, 1995; Giros et al, 1991; Park et al, 1995). At least seven distinct alternatively spliced D3 receptor variants are produced, including the full-length D3 receptor (called 'D3'), and a shorter receptor isoform, D3S, lacking 21 amino acids within the third cytoplasmic loop (Fishburn et al, 1993). Both D3 and D3S exhibit highaffinity dopamine binding. Five additional alternatively spliced variants have also been described, which do not bind dopamine, and are believed to function instead through the regulation of receptor dimerization (Snyder et al, 1991). These include D3 (TM3-del) (Giros et al, 1991; Snyder et al, 1991), D3 (TM4-del) (Nagai et al, 1993), D3 (O2-del) (Giros et al, 1991), rD3in (Pagliusi et al, 1993), and D3nf (Schmauss et al, 1993; Liu et al, 1994b). D3nf is the best characterized of the non-dopamine-binding splice

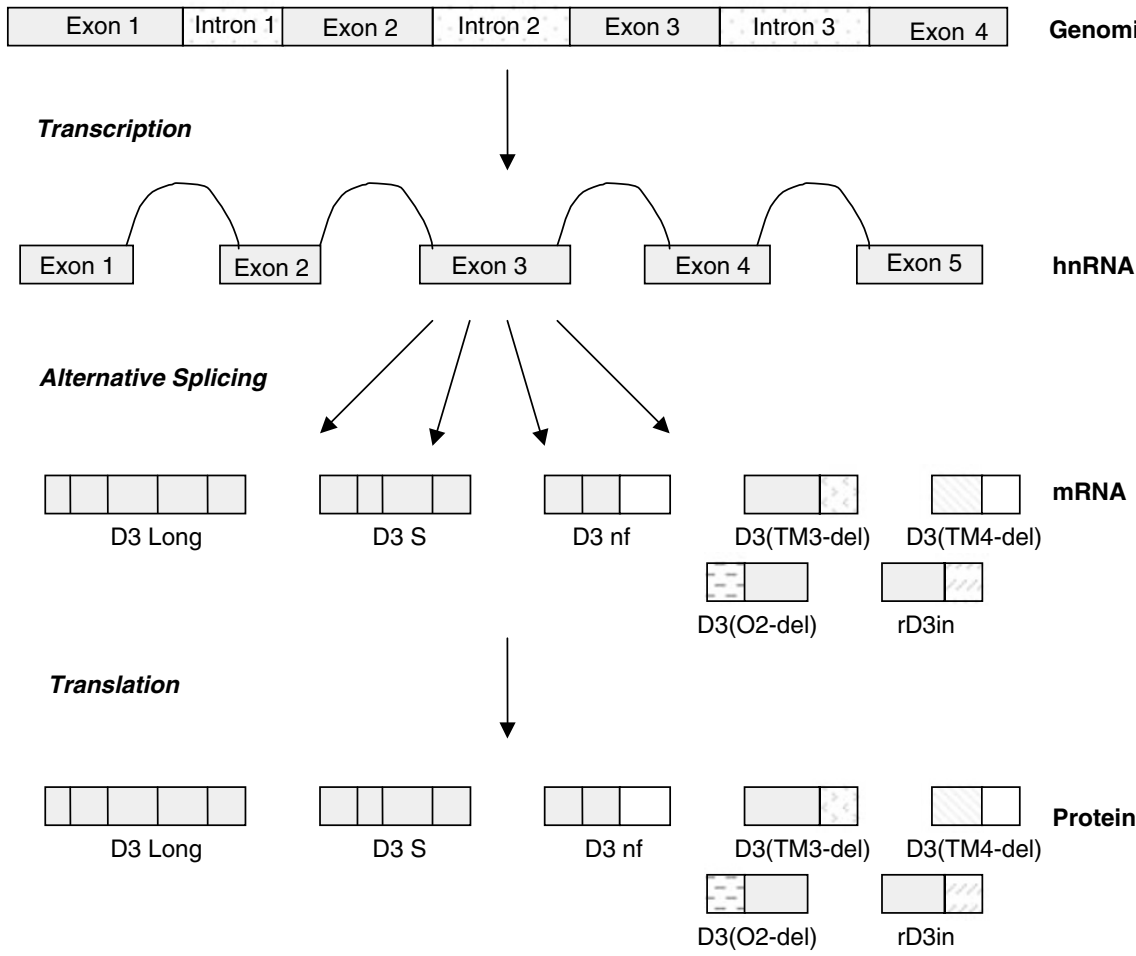

Figure I D3 receptor alternative splicing. 
variants. D3nf is formed through a deletion of $98 \mathrm{bp}$ in the third cytoplasmic loop, causing a coding frame shift resulting in the creation of a novel 55-amino-acid peptide and appearance of a new premature stop codon. The prematurely truncated protein thus lacks transmembrane domains 6 and 7 (Schmauss et al, 1993; Liu et al, 1994b), and does not bind dopamine (Elmhurst et al, 2000). D3nf mRNA and protein are expressed in rat, monkey, and human brain (Nimchinsky et al, 1997; Liu et al, 1994b). Importantly, the highly conserved nature of D3nf splicing and protein expression, from rat to human, suggest D3nf likely plays an important, although currently unknown, biological function. Evidence from three laboratories demonstrates that D3nf binds to the full-length D3 receptor subunit (Nimchinsky et al, 1997; Elmhurst et al, 2000; Karpa et al, 2000). D3nf expression inhibits dopamine binding to full-length D3 receptor (Elmhurst et al, 2000), and also redirects full-length D3 receptor localization away from the plasma membrane, and instead into an intracellular compartment (Karpa et al, 2000). Importantly, D3 mRNA expression is decreased in the cortex of schizophrenia patients (Schmauss et al, 1993), whereas increased D3nf splicing efficiency was observed in the cortex of postmortem tissue from schizophrenia patients (Schmauss, 1996). These findings suggest that increased D3nf expression may contribute to functional states of altered dopaminergic activity. Collectively, these observations suggest that, in a manner analogous to the way that dimerization plays an important role in the modulation of cell signaling for the homologous insulin- and gonadotropin-releasing hormone receptors (Kahn et al, 1981; Gregory et al, 1982), D3nf dimerization with full-length D3, D2, or D1 receptor could regulate dopamine signaling. Thus, alterations in D3 receptor isoform expression could modulate the effects of dopamine stimulation in altered functional states such as behavioral sensitization.

\section{D3 RECEPTOR ALTERNATIVE SPLICING AND BEHAVIORAL SENSITIZATION}

The information described above suggests a sensitization model of response to repetitive stimulant drug exposure illustrated in Figure 2: (1) AMPH increases extracellular dopamine, activating opposing second messenger signaling systems downstream of D1 and D3 receptor stimulation. (2) D3 and D1 receptor stimulations interact at the second messenger level (Ridray et al, 1998; Schwartz et al, 1998), for example, through opposite regulatory effects on ERK activity and Fos gene family expression (Zhang et al, 2004). This interaction is depicted in Figure 2 as occurring within the same cell because D3 and D1 receptors are frequently coexpressed (Schwartz et al, 1998); however, the interaction could also occur at the systems level (Xu et al, 1997; Jung and Schmauss, 1999; Levavi-Sivan et al, 1998). The D3 receptor has highest dopamine affinity, and persistent D3 receptor stimulation following dopamine transporter blockade results in homeostatic mechanisms opposing receptor stimulation. This homeostatic response would include (3) a change in D3 hnRNA alternative splicing in the cell nucleus resulting in increased D3nf expression. D3nf is a receptor splice variant whose function opposes D3 receptor stimula-

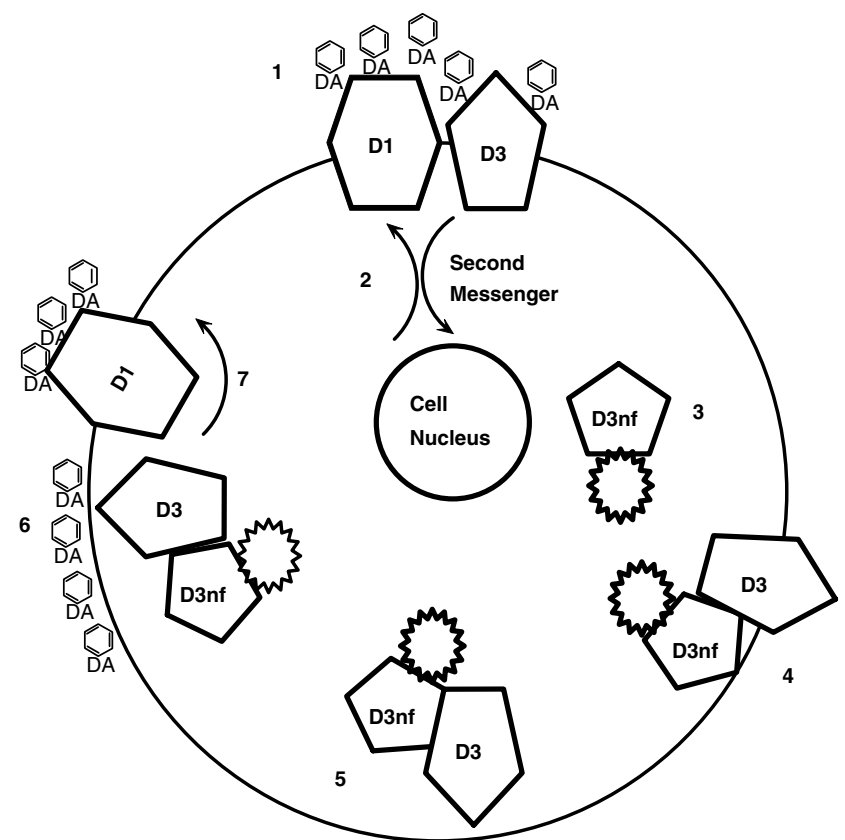

Figure 2 D3/ D3nf mechanism of behavioral sensitization to AMPH. (I) $\mathrm{AMPH}$ increases extracellular dopamine. (2) DI and D3 receptor stimulation activate opposing intracellular signaling systems. D3 receptor has highest dopamine affinity. D3 stimulation results in homeostatic mechanisms opposing receptor stimulation, including (3) increased D3nf expression. (4) D3nf and D3 dimerize, directing the D3/D3nf dimer (5) toward intracytoplasmic trafficking pools and removing D3 receptor from the synaptic membrane. (6) At the next AMPH exposure, D3 receptor is not available to bind dopamine. (7) The result is release of D3 receptormediated opposition to $\mathrm{DI}$ receptor stimulation of adenylate cyclase activity. For additional details see in the text.

tion. D3nf shares an NH3-terminus 'dimerization domain' with the D3 receptor, resulting in (4) dimerization between D3nf and D3. D3nf also contains a unique protein sequence at the $\mathrm{COOH}$-tail, which may direct the D3/D3nf dimer (5) toward intracytoplasmic trafficking pools, thereby removing the D3 receptor from a functional position at the synaptic membrane. In this manner, at the next AMPH exposure (6), the D3 receptor is localized in an intracytoplasmic pool, and is not available to bind dopamine at the synapse. The resulting loss of D3 receptor 'brake', at both the cellular and systems level, includes, for example (7), the loss of D3-receptor-mediated opposition to D1 receptor intracellular signaling.

\section{EVIDENCE FOR D3 RECEPTOR THEORY OF BEHAVIORAL SENSITIZATION}

Experimental evidence supporting the D3 receptor model of sensitization comes from three lines of data: (1) the effect of D3 receptor antagonists on the development of sensitization; (2) loss of D3 receptor function following sensitization; and (3) decreased D3 receptor mRNA and binding following sensitization.

If tolerance of persistent D3 receptor stimulation contributes to the development of sensitization, blockade with D3 receptor antagonist should inhibit the development of sensitization to dopamine agonists. Consistent with this 
prediction, studies in different laboratories demonstrate inhibition of locomotor sensitization by pretreatment with the D3 receptor antagonists nafadotride (Richtand et al, 2000), U99194A, or GR103691 (Chiang et al, 2003). Additionally, the effect of U99194A was attenuated by pretreatment with the D3 receptor agonist 7-OH-DPAT (Chiang et al, 2003), providing further evidence in support of a model in which $\mathrm{D} 3$ receptor stimulation contributes to the development of sensitization.

\section{BEHAVIORAL RESPONSE TO D3 RECEPTOR AGONIST IS DIMINISHED IN AMPH-SENSITIZED RATS}

A second, independent line of evidence regarding the D3 hypothesis relates to D3 function in sensitized animals. If persistent release of D3-receptor-mediated inhibitory influence contributes to the expression of sensitization, the behavioral response to D3 agonists should be attenuated in sensitized animals. Consistent with this prediction, D3receptor-mediated locomotor inhibition is dramatically reduced in sensitized rats (Richtand et al, 2003). We determined the behavioral response to $\mathrm{D} 3$ receptor agonists 7-OH-DPAT and PD 1289071 week following repetitive AMPH treatment. Locomotor response to novelty is inhibited by the D3 agonists PD 128907 (shown in Figure 3) and 7-OH-DPAT in animals pretreated with a 5-day saline injection regimen, whereas this D3-receptor-mediated locomotor inhibition is not detectable following completion of a sensitizing $\mathrm{AMPH}$ regimen. This study also found, unexpectedly, that the locomotor response to $\mathrm{AMPH}$, and locomotor inhibition by D3 agonist, are negatively correlated within individual animals, accounting for over $50 \%$ of the individual variance in locomotor response to $\mathrm{AMPH}$, and that this relationship is abolished following repetitive AMPH treatment. In combination, these findings suggest that release of D3-receptor-mediated inhibition contributes to the expression of behavioral sensitization (Richtand et al, 2003).

\section{LONG-TERM CONSEQUENCES OF STIMULANT DRUG EXPOSURE}

The third line of evidence regarding the D3 hypothesis relates to underlying mechanism. If a persistent decline of D3-receptor-mediated inhibition contributes to sensitization, the underlying mechanism should be evident through analysis of the effects of repetitive stimulant exposure on D3 mRNA, binding activity, downstream signaling pathways, or other indices of receptor function. The evidence in this area to date, on balance, has not been conclusive, perhaps in part because direct measures of D3 receptor function have been elusive. In support of the D3 receptor hypothesis, multiple studies in different laboratories have observed decreases in measures of D3 receptor expression in sensitized animals. D3 receptor mRNA and protein expression are both decreased in AMPH-sensitized rats (Chiang et al, 2003), and D3 binding in the nucleus accumbens is also decreased following locomotor sensitization to cocaine (Wallace et al, 1996). D3 receptor binding is also decreased in the nucleus accumbens in rat offspring exposed to stress in late pregnancy, a manipulation causing increased locomotor

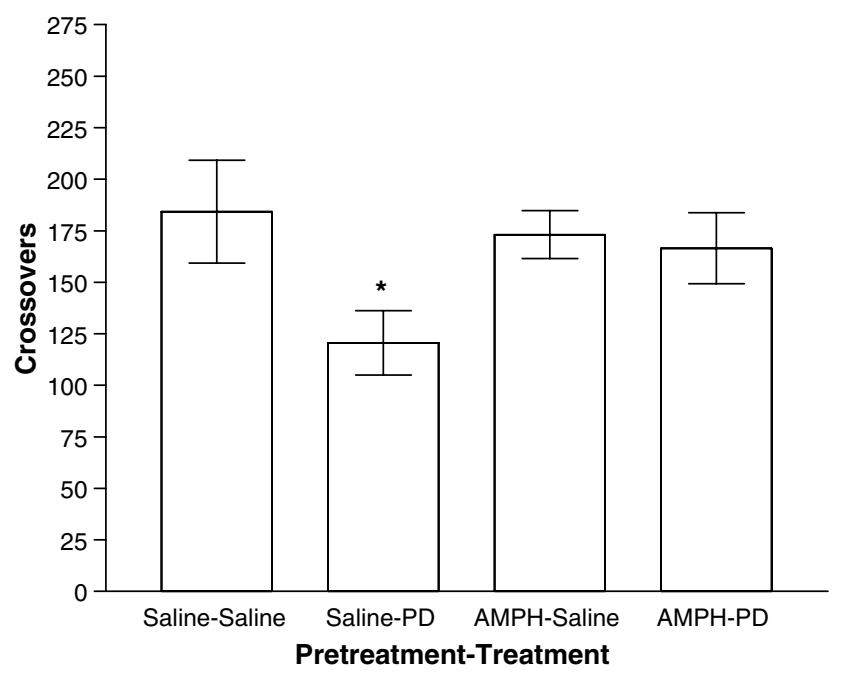

Figure 3 Behavioral response to PD 128907 is diminished in behaviorally sensitized rats. Locomotion following injection with saline and PD 128907 is shown following saline or AMPH pretreatment. Saline pretreatment group: *PD 128907 vs saline injection planned comparison $p=0.021$, one-tailed. AMPH pretreatment group: PD 128907 vs saline injection planned comparison $p=0.754$. Saline vs $A M P H$ pretreatment group response to saline injection mean comparison $p=0.368$, two-tailed Methods: Male Sprague-Dawley were treated in home cages for 5 consecutive days with either saline or AMPH (I mg/kg). On days 12-14 rats were injected in random order with either saline or PD I 28907 ( I $0 \mu$ g/ $\mathrm{kg}$ ) on a rotating basis, allowing each animal to be used as its own control to measure D3-agonist-mediated inhibitory effect. Data analysis by oneway ANOVA revealed no difference in order of injection (saline first or PD 128907 first). Crossover data from 0 to 180 min following injection with saline and PD 128907 were analyzed using ANOVA techniques for independent observations. Results are expressed as geometric mean number of crossovers, $\pm \mathrm{SE}$, for each group. Planned t-tests were performed for hypotheses of interest. Adapted from Richtand et al (2003).

response to novelty, more rapid locomotor sensitization, and increased AMPH self-administration (Henry et al, 1995). D3 receptor binding is also decreased in adult rats following neonatal hippocampal lesion (Flores et al, 1996), suggesting hyperlocomotor behavioral responses in that model also result from decreased D3 receptor inhibitory function (Wan and Corbett, 1997).

In contrast to the studies described above, we have not detected significant alterations in full-length D3 mRNA expression (Hondo et al, 1999) or D3 receptor binding in ventral striatum of AMPH-treated rats (Richtand et al, 2003). Studies of D3 expression in human cocainedependent subjects have also had conflicting results (Staley and Mash, 1996; Mash and Staley, 1999; Segal et al, 1997; Meador-Woodruff et al, 1995). In one series studying a small number of subjects ( $n=6$ /group), D3 receptor binding and mRNA were both increased in cocaine overdose victims in comparison to age-matched control subjects; however, comparable changes were not observed in cocaine delirium victims (Staley and Mash, 1996; Mash and Staley, 1999; Segal et al, 1997). In contrast, another study failed to detect any difference between control and cocaine-abusing subjects in D3 mRNA in autopsy tissue (Meador-Woodruff et al, 1995). None of the published studies to date have been designed to distinguish alternatively spliced D3 receptor isoforms. Future studies evaluating D3 receptor isoform expression, subcellular 
localization, and intracellular signaling pathways may be able to more clearly elucidate the mechanism underlying the decline in D3 receptor-mediated inhibitory function accompanying behavioral sensitization.

\section{CONCLUSIONS}

Behavioral sensitization may be accounted for in part by tolerance of D3-receptor-mediated inhibitory systems. Perturbations in D3-receptor-mediated inhibitory function may contribute to several neuropsychiatric disorders, including drug dependence, schizophrenia, and Parkinson's disease. Because highly selective D3 receptor ligands have been synthesized (Newman et al, 2005), identifying the role of the D3 receptor in the pathophysiology of each of these conditions could make novel approaches to drug treatment feasible. Importantly, D3 receptor tissue distribution is relatively limited within limbic brain regions, suggesting the potential for focused treatments with few side effects. Additionally, elucidating the role of alternative splicing pathways in behavioral sensitization may identify a novel mechanism at which to intervene both to prevent sensitization, as well as to potentially reverse sensitization through restoration of D3-mediated inhibitory function.

\section{ACKNOWLEDGEMENTS}

This work was supported by the Department of Veterans Affairs Medical Research Service, and National Institute of Drug Abuse (DA016778-01)

\section{REFERENCES}

Accili D, Fishburn CS, Drago J, Steiner H, Lachowicz JE, Park BH et al (1996). A targeted mutation of the D3 dopamine receptor gene is associated with hyperactivity in mice. Proc Natl Acad Sci USA 93: 1945-1949.

Ackerman JM, White FJ (1990). A10 somatodendritic dopamine autoreceptor sensitivity following withdrawal from repeated cocaine treatment. Neurosci Lett 117: 181-187.

Bell DS (1973). The experimental reproduction of amphetamine psychosis. Arch Gen Psychiatry 29: 35-40.

Bjijou Y, Stinus L, Le Moal M, Cador M (1996). Evidence for selective involvement of dopamine D1 receptors of the ventral tegmental area in the behavioral sensitization induced by intraventral tegmental area injections of D-amphetamine.J Pharmacol Exp Ther 277: 1177-1187.

Bouthenet ML, Souil E, Martres MP, Sokoloff P, Giros B, Schwartz JC (1991). Localization of dopamine D3 receptor mRNA in the rat brain using in situ hybridization histochemistry: comparison with dopamine D2 receptor mRNA. Brain Res 564: 203-219.

Chiang YC, Chen PC, Chen JC (2003). D(3) dopamine receptors are down-regulated in amphetamine sensitized rats and their putative antagonists modulate the locomotor sensitization to amphetamine. Brain Res 972: 159-167.

Costall B, Naylor RJ (1974). Extrapyramidal and mesolimbic involvement with the stereotypic activity of D- and L-amphetamine. Eur J Pharmacol 25: 121-129.

Creese I, Iversen SD (1972). Amphetamine response in rat after dopamine neurone destruction. Nat N Biol 238: 247-248.

Creese I, Iversen SD (1975). The pharmacological and anatomical substrates of the amphetamine response in the rat. Brain Res 83: 419-436.
Dalia A, Uretsky NJ, Wallace LJ (1998). Dopaminergic agonists administered into the nucleus accumbens: effects on extracellular glutamate and on locomotor activity. Brain Res 788: 111-117.

Diaz J, Levesque D, Griffon N, Lammers CH, Martres MP, Sokoloff $P$ et al (1994). Opposing roles for dopamine D2 and D3 receptors on neurotensin mRNA expression in nucleus accumbens. Eur $J$ Neurosci 6: 1384-1387.

Dreher JK, Jackson DM (1989). Role of D1 and D2 dopamine receptors in mediating locomotor activity elicited from the nucleus accumbens of rats. Brain Res 487: 267-277.

Ekman A, Nissbrandt H, Heilig M, Dijkstra D, Eriksson E (1998). Central administration of dopamine D3 receptor antisense to rat: effects on locomotion, dopamine release and $\left[{ }^{3} \mathrm{H}\right]$ spiperone binding. Naunyn Schmiedeberg's Arch Pharmacol 358: 342-350.

Ellinwood EHJ, Sudilovsky A, Nelson LM (1973). Evolving behavior in the clinical and experimental amphetamine (model) psychosis. Am J Psychiatry 130: 1088-1093.

Ellinwood Jr EH (1967). Amphetamine psychosis: I. Description of the individuals and process. J Nerv Ment Dis 144: 273-283.

Elmhurst JL, Xie Z, O'Dowd BF, George SR (2000). The splice variant $\mathrm{D} 3 \mathrm{nf}$ reduces ligand binding to the D3 dopamine receptor: evidence for heterooligomerization. Brain Res $\mathrm{Mol}$ Brain Res 80: 63-74.

Fishburn CS, Belleli D, David C, Carmon S, Fuchs S (1993). A novel short isoform of the D3 dopamine receptor generated by alternative splicing in the third cytoplasmic loop. J Biol Chem 268: $5872-5878$.

Flores G, Barbeau D, Quirion R, Srivastava LK (1996). Decreased binding of dopamine D3 receptors in limbic subregions after neonatal bilateral lesion of rat hippocampus. J Neurosci 16: 2020-2026.

Fog R, Randrup A, Pakkenberg H (1970). Lesions in corpus striatum and cortex of rat brains and the effect on pharmacologically induced stereotyped, aggressive and cataleptic behaviour. Psychopharmacologia 18: 346-356.

Fu D, Skryabin BV, Brosius J, Robakis NK (1995). Molecular cloning and characterization of the mouse dopamine D3 receptor gene: an additional intron and an mRNA variant. DNA Cell Biol 14: 485-492.

Giros B, Martres MP, Pilon C, Sokoloff P, Schwartz JC (1991). Shorter variants of the D3 dopamine receptor produced through various patterns of alternative splicing. Biochem Biophys Res Commun 176: 1584-1592.

Gregory H, Taylor CL, Hopkins CR (1982). Luteinizing hormone release from dissociated pituitary cells by dimerization of occupied LHRH receptors. Nature 300: 269-271.

Griffith JD, Cavanaugh J, Held J, Oates JA (1972). Dextroamphetamine: evaluation of psychotomimetic properties in man. Arch Gen Psychiatry 26: 97-100.

Griffon N, Crocq MA, Pilon C, Martres MP, Mayerova A, Uyanik G et al (1996). Dopamine D3 receptor gene: organization, transcript variants, and polymorphism associated with schizophrenia. Am J Med Genet 67: 63-70.

Gurevich EV, Joyce JN (1999). Distribution of dopamine D3 receptor expressing neurons in the human forebrain: comparison with D2 receptor expressing neurons. Neuropsychopharmacology 20: 60-80.

Henry C, Guegant G, Cador M, Arnauld E, Arsaut J, Le Moal M et al (1995). Prenatal stress in rats facilitates amphetamine-induced sensitization and induces long-lasting changes in dopamine receptors in the nucleus accumbens. Brain Res 685: 179-186.

Henry DJ, Greene MA, White FJ (1989). Electrophysiological effects of cocaine in the mesoaccumbens dopamine system: repeated administration. J Pharmacol Exp Ther 251: 833-839.

Henry DJ, White FJ (1991). Repeated cocaine administration causes persistent enhancement of D1 dopamine receptor sensitivity within the rat nucleus accumbens. J Pharmacol Exp Ther 258: 882-890. 
Higashi H, Inanaga K, Nishi S, Uchimura N (1989). Enhancement of dopamine actions on rat nucleus accumbens neurones in vitro after methamphetamine pretreatment. J Physiol 408: 587-603.

Hitzemann R, Wu J, Hom D, Loh H (1980). Brain locations controlling the behavioral effects of chronic amphetamine intoxication. Psychopharmacology (Berlin) 72: 93-101.

Hondo H, Spitzer RH, Grinius B, Richtand NM (1999). Quantification of dopamine D3 receptor mRNA level associated with the development of amphetamine-induced behavioral sensitization in the rat brain. Neurosci Lett 264: 69-72.

Jones SR, Lee TH, Wightman RM, Ellinwood EH (1996a). Effects of intermittent and continuous cocaine administration on dopamine release and uptake regulation in the striatum: in vitro voltammetric assessment. Psychopharmacology (Berlin) 126: 331-338.

Jones SR, O'Dell SJ, Marshall JF, Wightman RM (1996b). Functional and anatomical evidence for different dopamine dynamics in the core and shell of the nucleus accumbens in slices of rat brain. Synapse 23: 224-231.

Jung MY, Schmauss C (1999). Decreased c-fos responses to dopamine $D(1)$ receptor agonist stimulation in mice deficient for D(3) receptors. J Biol Chem 274: 29406-29412.

Kahn CR, Baird KL, Flier JS, Grunfeld C, Harmon JT, Harrison LC et al (1981). Insulin receptors, receptor antibodies, and the mechanism of insulin action. Recent Prog Horm Res 37: 477-538.

Kalivas PW, Alesdatter JE (1993). Involvement of $N$-methyl-Daspartate receptor stimulation in the ventral tegmental area and amygdala in behavioral sensitization to cocaine. J Pharmacol Exp Ther 267: 486-495.

Kalivas PW, Duffy P (1990). Effect of acute and daily cocaine treatment on extracellular dopamine in the nucleus accumbens. Synapse 5: 48-58.

Kalivas PW, Duffy P (1993). Time course of extracellular dopamine and behavioral sensitization to cocaine. I. Dopamine axon terminals. J Neurosci 13: 266-275.

Kalivas PW, Weber B (1988). Amphetamine injection into the ventral mesencephalon sensitizes rats to peripheral amphetamine and cocaine. J Pharmacol Exp Ther 245: 1095-1102.

Kamata K, Rebec GV (1984). Long-term amphetamine treatment attenuates or reverses the depression of neuronal activity produced by dopamine agonists in the ventral tegmental area. Life Sci 34: 2419-2427.

Karler R, Finnegan KT, Calder LD (1993). Blockade of behavioral sensitization to cocaine and amphetamine by inhibitors of protein synthesis. Brain Res 603: 19-24.

Karpa KD, Lin R, Kabbani N, Levenson R (2000). The dopamine D3 receptor interacts with itself and the truncated D3 splice variant d3nf: D3-D3nf interaction causes mislocalization of D3 receptors. Mol Pharmacol 58: 677-683.

Landwehrmeyer B, Mengod G, Palacios JM (1993). Differential visualization of dopamine $\mathrm{D} 2$ and $\mathrm{D} 3$ receptor sites in rat brain. A comparative study using in situ hybridization histochemistry and ligand binding autoradiography. Eur J Neurosci 5: 145-153.

Le Moine C, Bloch B (1996). Expression of the D3 dopamine receptor in peptidergic neurons of the nucleus accumbens: comparison with the D1 and D2 dopamine receptors. Neuroscience 73: 131-143.

Levant B (1998). Differential distribution of D3 dopamine receptors in the brains of several mammalian species. Brain Res 800: 269-274.

Levavi-Sivan B, Park BH, Fuchs S, Fishburn CS (1998). Human D3 dopamine receptor in the medulloblastoma TE671 cell line: cross-talk between D1 and D3 receptors. FEBS Lett 439: 138-142.

Levesque D, Diaz J, Pilon C, Martres MP, Giros B, Souil E et al (1992). Identification, characterization, and localization of the dopamine $\mathrm{D} 3$ receptor in rat brain using 7-[3H]hydroxy- $\mathrm{N}, \mathrm{N}$-din-propyl-2-aminotetralin. Proc Natl Acad Sci USA 89: 81558159.
Lieberman JA, Sheitman BB, Kinon BJ (1997). Neurochemical sensitization in the pathophysiology of schizophrenia: deficits and dysfunction in neuronal regulation and plasticity. Neuropsychopharmacology 17: 205-229.

Liu JC, Cox RF, Greif GJ, Freedman JE, Waszczak BL (1994a). The putative dopamine D3 receptor agonist 7-OH-DPAT: lack of mesolimbic selectivity. Eur J Pharmacol 264: 269-278.

Liu K, Bergson C, Levenson R, Schmauss C (1994b). On the origin of mRNA encoding the truncated dopamine D3-type receptor D3nf and detection of D3nf-like immunoreactivity in human brain. J Biol Chem 269: 29220-29226.

Mash DC, Staley JK (1999). D3 dopamine and kappa opioid receptor alterations in human brain of cocaine-overdose victims. Ann NY Acad Sci 877: 507-522.

Meador-Woodruff JH, Little KY, Damask SP, Watson SJ (1995). Effects of cocaine on D3 and D4 receptor expression in the human striatum. Biol Psychiatry 38: 263-266.

Menalled LB, Dziewczapolski G, Garcia MC, Rubinstein M, Gershanik OS (1999). D3 receptor knockdown through antisense oligonucleotide administration supports its inhibitory role in locomotion. Neuroreport 10: 3131-3136.

Nagai Y, Ueno S, Saeki Y, Soga F, Yanagihara T (1993). Expression of the D3 dopamine receptor gene and a novel variant transcript generated by alternative splicing in human peripheral blood lymphocytes. Biochem Biophys Res Commun 194: 368-374.

Nestler EJ, Terwilliger RZ, Walker JR, Sevarino KA, Duman RS (1990). Chronic cocaine treatment decreases levels of the G protein subunits $\mathrm{Gi}$ alpha and Go alpha in discrete regions of rat brain. J Neurochem 55: 1079-1082.

Newman AH, Grundt P, Nader MA (2005). Dopamine D3 receptor partial agonists and antagonists as potential drug abuse therapeutic agents. J Med Chem 48: 3663-3679.

Nimchinsky EA, Hof PR, Janssen WGM, Morrison JH, Schmauss C (1997). Expression of dopamine D3 receptor dimers and tetramers in brain and in transfected cells. J Biol Chem 272: 29229-29237.

Pagliusi S, Chollet-Daemerius A, Losberger C, Mills A, Kawashima E (1993). Characterization of a novel exon within the D3 receptor gene giving rise to an mRNA isoform expressed in rat brain. Biochem Biophys Res Commun 194: 465-471.

Park BH, Fishburn CS, Carmon S, Accili D, Fuchs S (1995). Structural organization of the murine D3 dopamine receptor gene. J Neurochem 64: 482-486.

Parsons LH, Justice JBJ (1992). Extracellular concentration and in vivo recovery of dopamine in the nucleus accumbens using microdialysis. J Neurochem 58: 212-218.

Paulson PE, Camp DM, Robinson TE (1991). Time course of transient behavioral depression and persistent behavioral sensitization in relation to regional brain monoamine concentrations during amphetamine withdrawal in rats. Psychopharmacology (Berlin) 103: 480-492.

Piazza PV, Deminiere JM, Le Moal M, Simon H (1989). Factors that predict individual vulnerability to amphetamine self-administration. Science 245: 1511-1513.

Pijnenburg AJ, Honig WM, Van Rossum JM (1975). Inhibition of $d$-amphetamine-induced locomotor activity by injection of haloperidol into the nucleus accumbens of the rat. Psychopharmacologia 41: 87-95.

Pritchard LM, Logue AD, Hayes S, Welge JA, Xu M, Zhang J et al (2003). 7-OH-DPAT and PD 128907 selectively activate the D3 dopamine receptor in a novel environment. Neuropsychopharmacology 28: 100-107.

Richtand NM, Goldsmith RJ, Nolan JE, Berger SP (2001a). The D3 dopamine receptor and substance dependence. J Addict Dis 20: 19-32.

Richtand NM, Kelsoe JR, Segal DS, Kuczenski R (1995). Regional quantification of D1, D2, and D3 dopamine receptor mRNA in rat brain using a ribonuclease protection assay. Brain Res $\mathrm{Mol}$ Brain Res 33: 97-103. 
Richtand NM, Logue AD, Welge JA, Perdiue J, Tubbs LJ, Spitzer $\mathrm{RH}$ et al (2000). The dopamine D3 receptor antagonist nafadotride inhibits development of locomotor sensitization to amphetamine. Brain Res 867: 239-242.

Richtand NM, Welge JA, Levant B, Logue AD, Hayes S, Pritchard LM et al (2003). Altered behavioral response to dopamine D3 receptor agonists 7-OH-DPAT and PD 128907 following repetitive amphetamine administration. Neuropsychopharmacology 28: 1422-1432.

Richtand NM, Woods SC, Berger SP, Strakowski SM (2001b). D3 dopamine receptor, behavioral sensitization, and psychosis. Neurosci Biobehav Rev 25: 427-443.

Ridray S, Griffon N, Mignon V, Souil E, Carboni S, Diaz J et al (1998). Coexpression of dopamine D1 and D3 receptors in islands of Calleja and shell of nucleus accumbens of the rat: opposite and synergistic functional interactions. Eur J Neurosci 10: $1676-1686$.

Roberts DC, Zis AP, Fibiger HC (1975). Ascending catecholamine pathways and amphetamine-induced locomotor activity: importance of dopamine and apparent non- involvement of norepinephrine. Brain Res 93: 441-454.

Robinson TE, Berridge KC (1993). The neural basis of drug craving: an incentive-sensitization theory of addiction. Brain Res Brain Res Rev 18: 247-291.

Robinson TE, Jurson PA, Bennett JA, Bentgen KM (1988). Persistent sensitization of dopamine neurotransmission in ventral striatum (nucleus accumbens) produced by prior experience with (+)-amphetamine: a microdialysis study in freely moving rats. Brain Res 462: 211-222.

Ross SB (1991). Synaptic concentration of dopamine in the mouse striatum in relationship to the kinetic properties of the dopamine receptors and uptake mechanism. J Neurochem 56: 22-29.

Sato M, Chen CC, Akiyama K, Otsuki S (1983). Acute exacerbation of paranoid psychotic state after long-term abstinence in patients with previous methamphetamine psychosis. Biol Psychiatry 18: 429-440.

Scarselli M, Novi F, Schallmach E, Lin R, Baragli A, Colzi A et al (2001). D2/D3 dopamine receptor heterodimers exhibit unique functional properties. J Biol Chem 276: 30308-30314.

Schmauss C (1996). Enhanced cleavage of an atypical intron of dopamine D3-receptor pre-mRNA in chronic schizophrenia. J Neurosci 16: 7902-7909.

Schmauss C, Haroutunian V, Davis KL, Davidson M (1993). Selective loss of dopamine D3-type receptor mRNA expression in parietal and motor cortices of patients with chronic schizophrenia. Proc Natl Acad Sci USA 90: 8942-8946.

Schwartz JC, Diaz J, Bordet R, Griffon N, Perachon S, Pilon C et al (1998). Functional implications of multiple dopamine receptor subtypes: the D1/D3 receptor coexistence. Brain Res Brain Res Rev 26: 236-242.

Segal DM, Moraes CT, Mash DC (1997). Up-regulation of D3 dopamine receptor mRNA in the nucleus accumbens of human cocaine fatalities. Brain Res Mol Brain Res 45: 335-339.

Segal DS, Geyer MA, Schuckit MA (1981). Stimulant-induced psychosis: an evaluation of animal models. In: Youdim $\mathrm{MBH}$, Lovenberg W, Sharman DF, Lagnado JR (eds). Essays in Neurochemistry and Neuropharmacology. John Wiley \& Sons, Ltd: New York. Vol. 5, pp 95-129.

Segal DS, Mandell AJ (1974). Long-term administration of $d$ amphetamine: progressive augmentation of motor activity and stereotypy. Pharmacol Biochem Behav 2: 249-255.

Segal DS, Schuckit MA (1983). Animal models of stimulantinduced psychosis. In: Creese I (ed). Stimulants: Neurochemical, Behavioral and Clinical Perspectives. Raven Press: New York. pp 131-167.

Segal DS, Weinberger SB, Cahill J, McCunney SJ (1980). Multiple daily amphetamine administration: behavioral and neurochemical alterations. Science 207: 905-907.
Snyder LA, Roberts JL, Sealfon SC (1991). Alternative transcripts of the rat and human dopamine D3 receptor. Biochem Biophys Res Commun 180: 1031-1035.

Sokoloff P, Martres MP, Giros B, Bouthenet ML, Schwartz JC (1992). The third dopamine receptor (D3) as a novel target for antipsychotics. Biochem Pharmacol 43: 659-666.

Sorg BA, Ulibarri C (1995). Application of a protein synthesis inhibitor into the ventral tegmental area, but not the nucleus accumbens, prevents behavioral sensitization to cocaine. Synapse 20: 217-224.

Staley JK, Mash DC (1996). Adaptive increase in D3 dopamine receptors in the brain reward circuits of human cocaine fatalities. J Neurosci 16: 6100-6106.

Stewart J, Vezina P (1989). Microinjections of Sch-23390 into the ventral tegmental area and substantia nigra pars reticulata attenuate the development of sensitization to the locomotor activating effects of systemic amphetamine. Brain Res 495: 401-406.

Surmeier DJ, Song WJ, Yan Z (1996). Coordinated expression of dopamine receptors in neostriatal medium spiny neurons. J Neurosci 16: 6579-6591.

Terwilliger RZ, Beitner-Johnson D, Sevarino KA, Crain SM, Nestler EJ (1991). A general role for adaptations in G-proteins and the cyclic AMP system in mediating the chronic actions of morphine and cocaine on neuronal function. Brain Res 548: 100-110.

Utena H (1966). Behavioral aberrations in methamphetamineintoxicated animals and chemical correlates in the brain. Prog Brain Res 21: 192-207.

Vezina P, Stewart J (1990). Amphetamine administered to the ventral tegmental area but not to the nucleus accumbens sensitizes rats to systemic morphine: lack of conditioned effects. Brain Res 516: 99-106.

Wallace DR, Mactutus CF, Booze RM (1996). Repeated intravenous cocaine administration: locomotor activity and dopamine D2/D3 receptors. Synapse 23: 152-163.

Wan RQ, Corbett R (1997). Enhancement of postsynaptic sensitivity to dopaminergic agonists induced by neonatal hippocampal lesions. Neuropsychopharmacology 16: 259-268.

Waters N, Svensson K, Haadsma-Svensson SR, Smith MW, Carlsson A (1993). The dopamine D3-receptor: a postsynaptic receptor inhibitory on rat locomotor activity. J Neural Transm Gen Sect 94: 11-19.

White FJ, Wang RY (1984). Electrophysiological evidence for A10 dopamine autoreceptor subsensitivity following chronic D-amphetamine treatment. Brain Res 309: 283-292.

Wolf ME (1998). The role of excitatory amino acids in behavioral sensitization to psychomotor stimulants. Prog Neurobiol 54: 679-720.

Wolf ME, Dahlin SL, Hu XT, Xue CJ, White K (1995). Effects of lesions of prefrontal cortex, amygdala, or fornix on behavioral sensitization to amphetamine: comparison with N-methyl-Daspartate antagonists. Neuroscience 69: 417-439.

Xu M, Koeltzow TE, Santiago GT, Moratalla R, Cooper DC, Hu XT et al (1997). Dopamine D3 receptor mutant mice exhibit increased behavioral sensitivity to concurrent stimulation of D1 and D2 receptors. Neuron 19: 837-848.

Zeng C, Wang Z, Li H, Yu P, Zheng S, Wu L et al (2006). D3 dopamine receptor directly interacts with $\mathrm{D} 1$ dopamine receptor in immortalized renal proximal tubule cells. Hypertension 47: 573-579.

Zetterstrom T, Sharp T, Marsden CA, Ungerstedt U (1983). In vivo measurement of dopamine and its metabolites by intracerebral dialysis: changes after $d$-amphetamine. J Neurochem 41: 17691773.

Zhang L, Lou D, Jiao H, Zhang D, Wang X, Xia Y et al (2004). Cocaine-induced intracellular signaling and gene expression are oppositely regulated by the dopamine D1 and D3 receptors. J Neurosci 24: 3344-3354. 